\title{
Responding to Climate-Induced Displacement in Bangladesh: A Governance Perspective
}

\author{
Chakma Kisinger ${ }^{1, *(D)}$ and Kenichi Matsui ${ }^{2}$ \\ 1 Doctoral Program in Sustainable Environmental Studies, University of Tsukuba, Ibaraki 305-8577, Japan \\ 2 Faculty of Life and Environmental Sciences, University of Tsukuba, Ibaraki 305-8577, Japan; \\ matsui.kenichi.gt@u.tsukuba.ac.jp \\ * Correspondence: kisingerchakma@yahoo.com
}

check for updates

Citation: Kisinger, C.; Matsui, K Responding to Climate-Induced Displacement in Bangladesh: A Governance Perspective. Sustainability 2021, 13, 7788. https:// doi.org/10.3390/su13147788

Academic Editors: Ortwin Renn and Pia-Johanna Schweizer

Received: 7 May 2021

Accepted: 8 July 2021

Published: 12 July 2021

Publisher's Note: MDPI stays neutral with regard to jurisdictional claims in published maps and institutional affiliations.

Copyright: (C) 2021 by the authors. Licensee MDPI, Basel, Switzerland. This article is an open access article distributed under the terms and conditions of the Creative Commons Attribution (CC BY) license (https:/ / creativecommons.org/licenses/by/ $4.0 /)$.

\begin{abstract}
Population displacement by extreme weather events have long plagued Bangladesh, a low-lying disaster-prone river delta. The country experiences yearly displacement of approximately one million people and losses of about $1 \%$ of its gross domestic product due to cyclones, floods, and riverbank erosion. This study examines how the Bangladesh government has managed climateinduced displacement with a particular focus on socioeconomic development policies. We analyzed the country's 1984 Land Reform Ordinance, the 2009 climate change strategy and action plan, the 1997 agricultural Khasland settlement policy, perspective plan for 2010-2021, poverty reduction strategy paper, and five-year plans to understand governance changes for displaced communities. We found that, overall, the central government implemented four main strategies. In the first strategy, Bangladesh resettled displaced people in cluster villages on public lands. Then, it provided life skills training (e.g., leadership, disaster preparedness, income generation) to rehabilitate the residents. The third strategy was to align resettlement efforts with local-level climate change adaptation and poverty reduction activities. Here, the central government and its seventeen departments collaborated with local councils to support resettled households under the social safety program. The fourth strategy was to diversify financial resources by obtaining more fund from donors and establishing its own financial mechanism. However, we also found that the decision-making and implementation process remained top-down without need assessment and community participation. This paper intends to offer insights on how similar challenged countries and regions may respond to climate displacement in the future.
\end{abstract}

Keywords: climate-induced displacement; rehabilitation; resettlement; cluster village; Bangladesh

\section{Introduction}

Disaster displacement occurs when natural hazards, such as storms and floods, compel people to leave their homes that were rendered at least temporarily uninhabitable [1,2]. Climate-induced displacement has been felt severely in least developed countries or regions due to poor infrastructure, poverty and social constraints, such as gender discrimination [3]. The 2014 report of the Intergovernmental Panel on Climate Change (IPCC) showed a trajectory of increased displacement of people by extreme weather events [1]. The Hyogo Framework for Action 2005-2015 urged countries to place high priority on building community resilience and preparedness. This international policy statement established a certain framework for many developing countries to follow in formulating policies for climate-induced displaced people (CIDP).

There is a consensus among international communities that climate-induced displacement worsens pre-existing stressors, such as poverty, underdevelopment, and gender inequality $[3,4]$. In recent decades, developing countries that are vulnerable to climate change impacts have focused on averting, minimizing, and adapting to climatic challenges [2,5]. Some countries with deltas and small islands adopted resettlement schemes for flood victims $[4,6-8]$. 
Within this context, Bangladesh received global attention for its high vulnerability to climate change impacts and its actions for displaced people. It is essentially a lowlying river delta with two thirds of its land under $5 \mathrm{~m}$ above sea level, and $61 \%$ of the population face flood risks [9]. Floods, cyclones and riverbank erosion have already displaced approximately 1.6 million people in the last four decades [10]. Additionally, 6 to 8 million people in coastal areas could potentially be displaced due to riverbank erosion [11]. According to the 2015 Climate Change Vulnerability Index, Bangladesh's economy is more at risk to climate change than any other countries. The economic loss from natural hazards reduces Bangladesh's gross domestic product (GDP) annually by $0.5 \%$ to $1 \%[12]$.

Having faced these challenges, Bangladesh has played a leading role in global climate dialogues and adaptation actions. It served as the president of the Climate Vulnerable Forum (CVF) in 2020 [13]. Since 1971, it has improved the early warning system and constructed $6000 \mathrm{~km}$ of embankment and polders, 2000 multipurpose cyclone shelters, and 200 flood shelters. All these resulted in reducing cyclone-induced death significantly in the last 40 years [14]. Bangladesh has also introduced salt-tolerant rice varieties and expanded mangrove plantations [11]. Along with embankment and polder, these measures protected and promoted agricultural production. In 2005, it adopted a National Adaptation Program of Action (NAPA), one of the first few countries to do so, followed by the 2009 Bangladesh Climate Change Strategy and Action Plan (BCCSAP) [11].

Past studies highlighted several adaptation practices for CIDPs in Bangladesh. Many of them identified direct and indirect displacement drivers. Direct drivers include recurring floods, cyclones, and riverbank erosion. Indirect drivers include drought and salinity intrusion [10,15-18]. Scholars also identified people's first responses to climatic displacement $[16,19]$. Some others examined livelihood uncertainty and stigmatization of displaced people under government resettlement schemes [19-23]. There are reports on the improved coping capacity of displaced people after resettling in shelters [24].

Among a growing number of studies on climate-induced displacement, what is critical but missing is the extent to which both central and local government response mechanisms took shape and how these mechanisms affected vulnerable people. Therefore, this paper attempts to examine Bangladesh's central and local government responses to climate-induced displacement with a particular focus on changes in response mechanisms, underlying socioeconomic policies that somewhat induced these changes, and future prospects of governing climate-induced disaster displacement. In doing so, it seeks to better understand how Bangladesh's post-displacement responses coherently or incoherently responded to its climate change and socioeconomic policies in the last five decades or the entire history of the country since independence from Pakistan. This paper offers one of the most thorough examinations of Bangladesh's policy changes and gaps on disaster displacement. In the following discussion we first explain about the methodology we used for examining government policy responses, followed by results and discussion of our investigation.

\section{Materials and Methods}

The following discussion in this paper is largely based on eight policy documents that are salient to understand national plans and actions for climate-induced displacement. All are written in Bengali:

1. The Land Reform Policy of 1984

2. Agricultural Khasland Settlement and Management Policy of 1997,

3. Bangladesh Climate Change Strategies and Action Plan (BCCSAP) of 2009,

4. National Disaster Management Plan of 2010,

5. Standing Orders on Disaster (SOD) of 2019,

6. Poverty Reduction Strategy Paper (PRSP) of 2009,

7. Seventh Five-Year Plan of 2016-2020, and

8. Perspective Plan of 2010-2021. 
These are the essential documents to understand the evolution of disaster displacement policies of Bangladesh. For example, the Land Reform Policy of 1984 set aside some tracts of public lands for resettling landless peasants. The Agricultural Khasland Settlement and Management Policy of 1997 laid the foundation for present-day disaster displacement responses in Bangladesh. This led to the formulation of the National Disaster Management Plan of 2010 and the Standing Orders on Disasters (SOD). These two documents help understand what the central government at the time intended and what management structure it wanted to formulate for climate-induced disaster affected people. The Poverty Reduction Strategy Paper (PRSP) and the Five-Year Plan are the most important documents to understand national poverty reduction strategies for climate victims. The Perspective Plan 2010-2021 is the national medium-term strategic paper that describes the government's priority issues to address. It helps us understand the extent to which disaster displacement issues were prioritized among other urgent issues.

In addition, from April to August 2020, the lead author, a cadre officer of the Bangladesh public administration, interviewed 18 local committee heads and 18 member secretaries at all subdistrict climate victim resettlements and disaster management committees in the southeast coast. The interview was carried out through telephone calls that lasted from 20 to $30 \mathrm{~min}$ each. In 2021, he also interviewed two key government officials, a director of the Prime Minister's Office and a deputy project director for phase 2 of the Ashrayan Project, which is one of resettlement projects. Each interview lasted 40 to $50 \mathrm{~min}$, carried out on an online media messaging platform, such as WhatsApp. The interview questions focused on management strategies and challenges they observed in handling climate-induced displaced people. The information the interviewees shared was cross-checked with available documents. To conduct research for this paper, we obtained permission from a respective Bangladesh agency and received a multiple-year fellowship from the Japan International Cooperation Center (JICE).

In analyzing the collected information, we tried to understand how past governments recognized climate-induced people with the focus on post-disaster rehabilitation frameworks, institutional arrangement for resource mobilization and immediate responses for climate victims, and their consistency to overall resettlement programs. Through the content analysis, we additionally examined how financial resources for displaced people have been diversified or strengthened in government programs.

Although past climate change studies have popularized the concept of CIDP, we do not yet have its widely accepted definition partly due to varied recognitions by countries and regions. The term has often been interchangeably used with environmental refugee, climate refugee, and internally displaced people. In its Climate Victims Rehabilitation Project of the Ministry of Land, Bangladesh defined CIDPs as landless and homeless destitute families affected and displaced by climate change, riverbank erosion, and other natural disasters [25]. In this paper, the term "climate victim" refers to poor homeless people who were displaced by climate change related disasters. The term "resettlement" is defined as the government action to resettle those who were displaced by climatic events, such as flood, cyclone, riverbank erosion in a cluster village. "Rehabilitation" means a set of government actions to restore displaced people's livelihoods. Relevant local government councils that implement these actions are Union Parishad and Upazila Parishad.

To mainstream climate change adaptation in state policies, Saito [26] emphasized the importance of coordination, recognition, financial feasibility, and implementation experience. Following this, the above eight policy documents were analyzed with four indicators: (1) post-displacement response, (2) paradigm shift from 1971 to 2020, (3) cross-jurisdictional collaboration, and (4) resource diversification. The first indicator examines government's current strategies for CIDPs. The second indicator examines policy paradigms that evolved in the last five decades to better understand policy gap and coherence. The third indicator clarifies cross-jurisdictional implementation coordination for post-displacement governance. The fourth indicator examines the financial resource mobilization for resettling climate victims. 


\section{Results and Discussion}

\subsection{Post-Displacement Governance for Climate Victims}

Our research on the Bangladesh government's CIDP strategies found that its postdisplacement governance is largely characterized by resettlement and rehabilitation activities with particular emphasis on (1) resettlement in constructed houses, (2) rehabilitation through capacity building, and (3) socioeconomic resilience to reduce disaster vulnerabilities (see Figure 1).

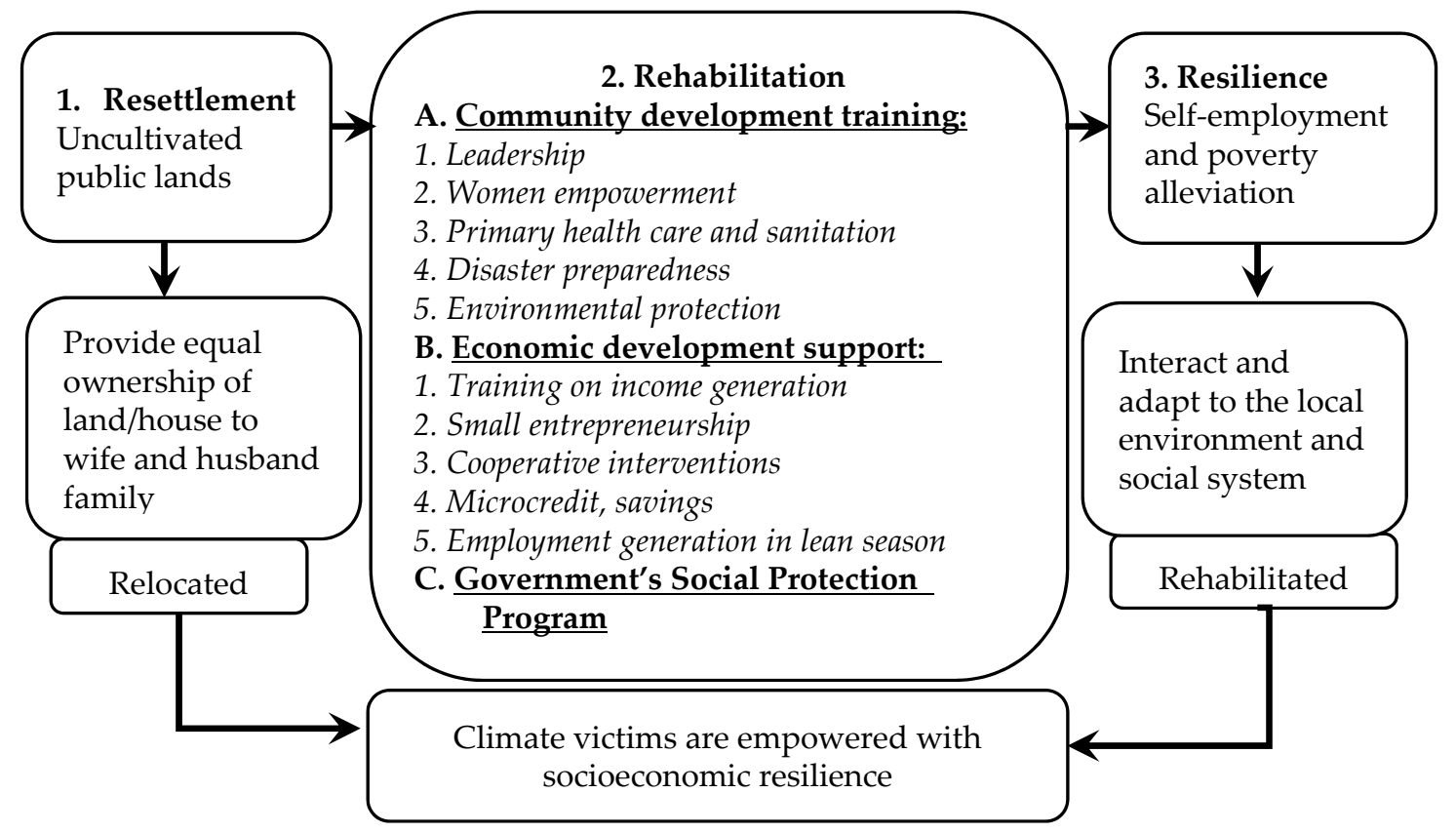

Figure 1. Post-displacement governance model in Bangladesh (source: own work).

Documents of the Land Ministry's Climate Victim Rehabilitation Project showed that each resettlement was supported by a rehabilitation process, such as community development training and economic development promotion [25]. Community development included such topics as leadership, disaster preparedness, primary health care and sanitation. The economic development included microcredit loans. One of the significant actions for resettling climate victims is the food for work program of the Department of Disaster Management (DDM). The DDM distributes $30 \mathrm{~kg}$ of food grains to each resettled household. It also hires them for rural road maintenance works. The central government's seventeen departments and elected local councils in a subdistrict implement skill development training, microcredit support and social protection programs. The central-local institutional engagement showed an integrated post-displacement governance.

\subsection{Paradigm Shift of the Post-Displacement Governing Policies}

\subsubsection{Changes in Post-Displacement Governance from 1971 to 2009}

As early as the 1970s, Bangladesh recognized the importance of helping CIDPs. At that time, post-displacement actions were carried out as part of poverty reduction and economic development. A severe tropical cyclone in 1970 killed approximately 500,000 people [14]. After independence in 1971, the government allocated uncultivated public lands or Khaslands for displaced households by the Presidential Order 98 of 1972. It also promoted farming in resettled areas. Since then, the country experienced several policy changes, as shown in Table 1.

In the mid-1980s, the central government attempted to prevent large-scale land ownership by limiting private land ownership to less than 60 standard bighas (i.e., 33 acres or 133,546 square meters). This was stipulated in Section 4(1) of the 1984 Land Reform 
Ordinance (LRO) [27]. One of the reasons to do so was to secure land for landless people to resettle. Until 1997, Bangladesh had interchangeably used the terms landless and climate victims. The 1997 Khasland Settlement and Management Policy clarified the definition of the terms along with a cluster village establishment guideline. However, Section 7(1) of the LRO authorizes the Land Ministry to allocate any Khasland fit for homestead use in rural areas to "landless farmers" on a priority basis. The central government also built corrugated iron sheet houses and alloted one acre of Khasland for each displaced household.

Table 1. Policy changes of climate induced post-displacement governance in Bangladesh.

\begin{tabular}{ccccc}
\hline Decades & Post-Displacement Actions & Major Policies/Laws & Approach \\
\hline $1971-1979$ & $\begin{array}{c}\text { Homeless people were placed in } \\
\text { shelters. }\end{array}$ & Presidential Order 98 of 1972 & Resettlement \\
\hline 1980-1989 & $\begin{array}{c}\text { Private land ownership was } \\
\text { restricted to increase public lands } \\
\text { for resettlement and farming. }\end{array}$ & Land Reform Ordinance 1984 & Resettlement and farming \\
\hline 1990-2000 & $\begin{array}{c}\text { Tin-shed houses were built in } \\
\text { cluster villages. }\end{array}$ & $\begin{array}{c}\text { Khasland Management and } \\
\text { Settlement Policy 1997 }\end{array}$ & Shelter in cluster village \\
\hline 2000-2009 & $\begin{array}{c}\text { Resettlement was enhanced } \\
\text { through social protection measures } \\
\text { (e.g., poverty/disaster risk } \\
\text { reduction). }\end{array}$ & $\begin{array}{c}\text { Comprehensive Disaster } \\
\text { Management Program 2005, } \\
\text { BCCSAP 2009, PRSP 2009 }\end{array}$ & Shelter and rehabilitation \\
\hline 2010-2020 & $\begin{array}{c}\text { Followed BCCSAP to enhance } \\
\text { social protection, capacity building } \\
\text { and local governance integration. }\end{array}$ & $\begin{array}{c}\text { Climate Change Trust Act } \\
\text { 2010, NPDM 2010, Climate } \\
\text { Fiscal Framework 2014 }\end{array}$ & Capacity building approach \\
\hline
\end{tabular}

In the mid-1990s, the central government made more systemic approaches to resettlement schemes by replacing one-off resettlements with resettlement-cum-livelihood support apporaches. For these, the government engaged with various ministries to introduce more socioeconomic development programs for resettling climate victims. This was typically seen in the 1994 Char Development and Settlement Project (CDSP). The CDSP was operated from 1994 to 2018 with four phases. Ministries responsible for land, water, local government, agriculture, and livestock took responsibilities. Additionally, district and subdistrict administrations were involved [28]. It provided each displaced household with both constructed houses and land (e.g., a tin-shed house and 0.8 to 1 acres of Khasland or charland: These Bengali terms mean the land that gradually emerged from seas and rivers through accretion and erosion process). The Ministry of Land administers khaslands. In so doing, once sparsely located houses were brought under a cluster village. Priority was given to those who were occupying khaslands after being displaced from their original houses due to riverbank erosion or cyclone. Simultaneously, the government began constructing cyclone shelters, water management infrastructure, such as dams and irrigation canals, to promote socioeconomic and agricultural development activities. The abovementioned 1997 Khasland Settlement Policy then established a priority list, in which those replaced from riverbank erosion and floods were the highest priority [29]. This policy directed to preserve khaslands only for landless resettlement schemes.

From 2000 to 2009, the government began synergizing resettlement, risk reduction and climate change adaptation policies. While maintaining the past priority actions, it added a concept of disaster resilience in order to improve the resettlement effectiveness and sustainability. For example, it began constructing semi-pucca houses instead of tin-shed ones to promote resilient structures in cluster villages; this was stipulated in phase 1 of the Ashrayan resettlement project [30] and phase 2 of the CDSP. Additionally, it began promoting livelihood adaptation through agricultural activities under the comprehensive Disaster Management Program (CDMP) of 2005-2009. The CDMP was designed to improve institutional and community capacity for disaster risk reduction. It was implemented by 
the Ministry of Disaster Management and Relief and the UNDP. Vij et al. [31] called the changes in resettlement policies a paradigm shift from the policies of the late 1990s as the Bangladesh government began focusing more on climate change actions. However, rather than a shift, the CDMP can also be interpreted as a successive evolution of past resettlement policies, partly in response to calls for action from international organizations and donors.

In 2009, the synergy of resettlement schemes and climate change governance gained momentum when the government adopted the Bangladesh Climate Change Strategies and Action Plan (BCCSAP). It established six main policy pillars: (1) food security, social protection and health, (2) comprehensive disaster management, (3) resilient infrastructure, (4) research and knowledge management, (5) mitigational measures, and (6) capacity building and institutional strengthening [11]. Program 6 of BCCSAP pillar 4 has a protocol to provide resettlement and rehabilitation support to displaced climate victims. To do this, the government linked BCCSAP's capacity-building and social protection programs with its short-term poverty reduction strategy paper (PRSP) and medium-term Perspective Plan for 2010-2021. This was stipulated in policy matrices 7 and 8 of the 2009 PRSP [32]. Clause 13(4) of the Perspective Plan reads that capacity-building and resource mobilization should benefit vulnerable communities to extreme climatic events [33].

\subsubsection{Displaced Climate Victims in Post-2009 Development Agenda}

Since 2009, the Bangladesh government has diversified resource mobilization efforts and linked BCCSAP programs to local development agendas. Instead of abandoning the previous resettlement strategies, it attempted to connect them to the global climate funding mechanisms. For this purpose, a climate change trust fund was established by allocating money from national budget and donors. This was stipulated in Sections 3 and 5 of the 2010 Climate Change Trust Act [34]. Ministries that were responsible for adaptation and capacity-building programs received money from this trust fund. Its funded programs addressed six pillars of the BCCSAP. At the local level, Union Parishad and Upazila Parishad councils took responsibility for rehabilitating households in small-scale capacity building programs, such as poultry rearing, handicraft making, and disater preparedness. These councils also provided seasonal employment, such as repairing rural roads.

In the 2010s, Bangladesh's resettlement actions for disaster displaced people further incorporated disaster risk reduction, which is the second pillar of the BCCSAP. The central government established three areas of focus that should guide policy implementation for displaced climate victims: (1) priority on disaster management, (2) relief, resettlement and social protection, and (3) capacity building and poverty reduction [35,36]. For example, it scaled up disaster resilient cluster village houses (e.g., pucca houses) in resettling climate victims [37]. It also introduced more capacity-building actions, such as microcredit, small entrepreneurship, and cooperative interventions [33]. The Disaster Management Department enhanced employment generation (e.g., food/cash for work) and a social protection program (e.g., vulnerable group feeding, children education allowance).

\subsection{Cross-Jurisdictional Collaboration for Displaced People}

In administering displacement affairs, jurisdictional responsibilities fell on different ministries over time, showing the policy emphasis of the time. Resettlement activities in the early 1970s were administered mainly by the Ministry of Land, whereas the Ministry of Disaster Management and Relief took responsibility for rehabilitation actions. This jurisdictional arrangement continued until the adoption of the CDSP project in the early 1990s.

The combined effort for resettlement and rehabilitation began under the 1994 CDSP. This project needed coordination among ministries responsible for land management, agriculture, water resources and local government [28]. This was an attempt to promote agriculture-based livelihood support for resettled households in Khasland. Then, the 1997 Khasland settlement policy engaged ministries, such as (1) environment and forest, (2) law, and (3) home affairs along with the leading Ministry of Land [29]. This policy included 
local council members in district and subdistrict committees. For example, Union Parishads were to confirm the identity and location of displaced households and recommend to the committees for assigning victims to cluster villages. This interministerial engagement continued until 2009, when the government adopted the BCCSAP that involved the ministries concerned with social protection and capacity-building activities.

In the 2010s, the government attempted to integrate resettlement schemes into BCCSAP's governing pillars. In so doing, the government promoted networking and effective interactions/communications among government agencies and local councils. At the central level, the central advisory council (headed by a minister) and the central steering committee (headed by the Principal Secretary to the Prime Minister Office) were established [30]. Upon request, the central advisory committee offers necessary policy reform ideas to the Parliament regarding climate victim resettlement and rehabilitation. The steering committee oversees institutional collaboration at national, subnational and local levels. Secretaries of 14 ministries and directorates that administer social protection programs sit in steering committees. To localize the post-displacement responses, the subdistrict level committee engages local councils and central government's seventeen departments to implement rehabilitation schemes [30]. Local councils engage resettling households in local employment generation schemes, whereas central government departments provide capacity-building support, such as skill development training and microcredit financing. This cross-jurisdictional collaboration has enhanced displacement governance and improved the past governance practices before 2009.

\subsection{Resource Diversification for Governing Climate Victims}

Another salient finding we made after examining resettlement scheme documents of the last 50 years was that financial support policies shifted from unilateral to multilateral partnership. Bangladesh used to depend solely on a limited number of donors, but, in time, it has acquired skill and know-how to create self-financing. In the 1970s, soon after independence, the Bangladesh government typically depended on financial and technical support from the United Nations and other foreign countries. For example, the Char Development and Settlement Project in the 1970s was financed by the Netherlands, which was later transformed into a large-scale resettlement project in 1994 [28]. In 2011, the International Fund for Agricultural Development (IFAD) began financing this project in collaboration with the Netherlands. Money for resettlement from the Bangladesh government remained nominal until the establishment of the Climate Change Trust Fund (BCCTF) in 2009 [34]. Following the BCCTF, World Bank-led donors also created a separate fund called the Bangladesh Climate Change Resilience Fund (BCCRF) in 2010 to support climate change governance through NGOs.

However, the coordination of allocating budget among various sectors remained challenging. The Climate Fiscal Framework (CFF) in 2014 was created to mitigate this challenge by clarifying a financial management roadmap. This roadmap emphasized the importance of building more climate resilient houses, ensuring social protection and enhancing capacity building among displaced communities. The government has allocated specific budget for the socioeconomic rehabilitation of displaced victims in the national budget.

Table 2 shows a steady increase in the budget allocation of six BCCSAP actions from 2016 to 2021 . This climate budget consisted of 7 to $8 \%$ of the national budget during this period. In particular, the government tended to focus on food security, social protection and health. However, some studies have shown some shortcomings behind this large budget allocation. Whilst it placed much emphasis on food security, social protection and health, not much of the money was spent on women and children welfare. For example, from 2014 to 2019, the Bangladesh Climate Change Trust Fund allocated only $0.1 \%$ of the budget to the Ministry of Health and Family Welfare and $0.07 \%$ to the Ministry of Women and Children Affairs [38,39]. Another study found that only four gender-specific programs existed among 44 BCCSAP programs [40]. 
Table 2. Budget allocation trend under climate financing in Bangladesh.

\begin{tabular}{|c|c|c|c|c|}
\hline \multirow{2}{*}{ BCCSAP Thematic Areas } & \multicolumn{4}{|c|}{$\begin{array}{c}\text { Fiscal Year Budget } \\
\text { Bangladesh Taka (BDT) and \% of } A\end{array}$} \\
\hline & 2016-2017 & 2018-2019 & 2019-2020 & $2020-2021$ \\
\hline \multirow{2}{*}{$\begin{array}{l}\text { Food security, social protection, } \\
\text { and health }\end{array}$} & 7065.7 & 8890.9 & 9233.6 & 9992.71 \\
\hline & $(49.3 \%)$ & $(41.5 \%)$ & $(38.9 \%)$ & $(41.25 \%)$ \\
\hline \multirow{2}{*}{ Comprehensive disaster management } & 1777.8 & 1997.4 & 2134 & 1810.74 \\
\hline & $(12.4 \%)$ & $(9.3 \%)$ & $(9 \%)$ & $(7.47 \%)$ \\
\hline \multirow{2}{*}{ Infrastructure } & 2395.3 & 5726.5 & 6787.8 & 6303.85 \\
\hline & $(16.7 \%)$ & $(26.7 \%)$ & $(28.6 \%)$ & $(26 \%)$ \\
\hline $\begin{array}{l}\text { Research and knowledge management } \\
\text { (e.g., displaced people's rehabilitation, } \\
\text { monitoring) }\end{array}$ & $\begin{array}{l}805.7 \\
(5 \%)\end{array}$ & $\begin{array}{l}857.8 \\
(4 \%)\end{array}$ & $\begin{array}{c}894.4 \\
(3.8 \%)\end{array}$ & $\begin{array}{l}848.62 \\
(3.5 \%)\end{array}$ \\
\hline Mitigation and low-carbon development & $\begin{array}{l}1110.9 \\
(78 \%)\end{array}$ & 2987.1 & 3514.7 & 4004.37 \\
\hline Capacity building and institutional & $\begin{array}{l}(1.8 \%) \\
1167.7\end{array}$ & $\begin{array}{c}(13.9 \%) \\
971.1\end{array}$ & $\begin{array}{c}(14.8 \%) \\
1195.2\end{array}$ & $\begin{array}{c}(16.53 \%) \\
1266.30\end{array}$ \\
\hline strengthening & $(8.2 \%)$ & $(4.5 \%)$ & $(5 \%)$ & $(5.2 \%)$ \\
\hline Total climate budget & 14,323 & $21,430.8$ & $23,759.6$ & 24,226 \\
\hline Percent of the national budget & $7.4 \%$ & $8.1 \%$ & $7.8 \%$ & $7.5 \%$ \\
\hline
\end{tabular}

Source: Adopted from [41]; 1BDT = US\$0.012 approx.

Our further examination of budget allocation, however, found that this discrepancy was somehow adjusted. For example, resettlement and rehabilitation activities received 3.5 to $5 \%$ of the climate budget under the BCCSAP's research and knowledge management theme. In addition, Bangladesh received approximately US $\$ 71$ million from the BCCRF, including US $\$ 23$ million for recovery and rehabilitation actions of cyclone victims [41]. Furthermore, local government laws have allowed Union Parishads and Upazila Parishads to support landless climate victims through local government budget. For example, each Union Parishad allocates 5 to $7 \%$ of the annual budget for capacity building of climate victims [42,43].

In the last 10 years, BCCSAP implementing ministries have, overall, improved financial managemet capacity. This was partly due to the adoption of a ministry-based priority matrix in the PRSP. For example, matrix 8 instructs to rehabilitate assetless and homeless climate victims. Then, the government allocated money to the Ministry of Land to implement climate victim resettlement schemes under BCCSAP pillar 4. It also allocated money to other ministries that are responsible for climate victim rehabilitation under pillar 1 (i.e., food security, social protection and health) and pillar 2 (i.e., comprehensive disaster management). Our analysis found that the government has improved its capacity for acquiring large-scale funds (Table 3 ).

Table 3. Budget utilization of Bangladesh's Ashrayan 2 resettlement project.

\begin{tabular}{ccccc}
\hline \multirow{2}{*}{ Year } & \multicolumn{2}{c}{ Budget $\begin{array}{c}\text { Utilization (Million US \$) } \\
\text { Utilized }\end{array}$} & $\begin{array}{c}\text { Percent of } \\
\text { Unutilized }\end{array}$ & Utilization \\
\hline 2010 & 1.93 & 1.93 & 0.00 & 100.00 \\
2011 & 1.71 & 1.68 & 0.03 & 98.33 \\
2012 & 1.42 & 1.39 & 0.03 & 98.06 \\
2013 & 1.95 & 1.91 & 0.03 & 98.35 \\
2014 & 2.36 & 2.33 & 0.03 & 98.94 \\
2015 & 2.48 & 2.46 & 0.02 & 99.15 \\
2016 & 3.53 & 3.46 & 0.08 & 97.80 \\
2017 & 14.33 & 14.30 & 0.03 & 99.79 \\
2018 & 5.31 & 5.28 & 0.03 & 99.40 \\
2019 & 5.31 & 5.23 & 0.08 & 98.48 \\
\hline
\end{tabular}




\section{Challenges to Displacement Governance}

Our analysis of past policies and actions for displaced communities found a persistent policy gap between local needs and policy visions for the last 50 years. This gap was largely engendered by the way policies were formulated unilateraly. In the 1970s and 1980s, government administrations had the power to decide how Khasland was to be set aside for and distributed to landless climate victims without consultation processes. Government Memo 71/1971 of the Board of Revenue and Presidential Order 98/1972, for example, authorized responsible agencies to take action, with no local engagement required [45]. Memo 71 simply directed the commissioner and deputy commissioners to resettle landless families in agricultural Khaslands. The Presidential Order limited private lands within 100 bighas. The 1984 Land Reform Order further reduced this to 60 bighas.

This persistent neglect to need-based processes continued till the 1997 Khasland settlement policy, which established national and subnational committees to secure implementation processes. However, committee members tended to engage mainly with bureaucrats, parliament members, local councils, and the Minister to the Land Ministry [29]. This lack of meaningful consultation with local people and victims largely continued to influence resettlement policies. Therefore, climate victims do not have sufficient opportunities to communicate with policymakers. McAdam [4] rightly noted this disconnect as a coordination gap in Bangladesh's climate governance.

Another policy gap has been the way cluster village houses were built without clear understanding of the people who use them. Clause 10 of the Ashrayan 2 project guideline reads that the floor space of each allocated house is either $26 \mathrm{~m}^{2}$ (pucca) or $24 \mathrm{~m}^{2}$ (corrugated iron-sheet) [30]. This size is too small for resettling households. A study found that the average household size of resettling households in cluster villages was five [21].

There has been some disconnect among responsible administrations in governing disaster displacement issues. Currently, financing is coordinated by the Ministry of Finance, whereas the Ministry of Land looks after resettlement schemes and the Ministry of Disaster Management and Relief is responsible for social protection activities. Although this jurisdictional compartmentalization and overlap are nothing strange in other countries, a lack of coordination among government stakeholders has led to the delay in decision-making and disaster responses when climate victims need immediate support to recover from disaster damage. For example, when a major flood affected delta communities in mid-July 2017, government aid did not reach the victims in many parts until mid-August, even though the central government quickly disbursed relief money [46].

Another formidable challenge for government officials has been a lack of uniformly organized information to identify climate victims to connect with humanitarian protection measures. This bookkeeping problem is interlinked to a lack of uniformly understood term to help climate victims. Displaced individuals were categorized as "landless" under the 1997 Khasland management policy, "environmental refugee" in the 2009 BCCSAP, and "climate victims" in the Land Ministry's climate victim resettlement project. Some terms, such as "environmental refugee", do not fall under global humanitarian protection. Scholars, such as Zetter [47], and McAdam [4] suggested that the term "refugee" did not help individuals to claim legal protection under international refugee conventions.

\section{Conclusions}

This paper discussed Bangladesh's governing strategies for displaced climate victims with particular emphasis on four specific indicators to understand post-displacement policies. It has identified four particular governing strategies. The first strategy was that the government initially resettled displaced households by allocating houses in cluster villages on public lands. The second strategy was that the government trained resettling people to develop income-generating skills. This support was followed by microcredit financing options and social protection. Here, the central government attempted to link ministries and local councils. The third strategy of the government was to align resettlement efforts with local-level climate change adaptation and poverty reduction activities. In so doing, 
the government engaged local councils, such as Union Parishads and Upazila Parishads. The fourth strategy focused on diversifying financial resources by obtaining more funding from donors and establishing its own financial mechanism.

Another objective of this study was to understand how post-displacement responses have changed over time by incorporating urgent social welfare concerns such as poverty reduction, disaster management, and climate change adaptation. We highlighted a paradigm shift from the 1970s to the 2010s. During this period, government aid shifted its focus from one-off resettlement and poverty relief to multi-purpose socioeconomic benefits for climate victims. In executing climate victim resettlement schemes, the Bangladesh government evolved by departing from donor dependence to partnership-building approaches. The BCCSAP of 2009 played a pivotal role in more comprehensively integrating and coordinating actions for displaced climate victims as part of national priorities.

Among these strategies, one of the significant challenges Bangladesh still faces today is to induce meaningful community participation, including climate victims at cluster villages, in decision-making processes. The rehabilitation guidelines do not clarify the role resettled climate victims can play in decision-making processes. It is critical to find a way to deal with a disconnect between local needs and central government visions or those of international organizations so that local aids for climate victims are more effectively mobilized.

Here, another fundamental question can be raised as to how rural Bangladesh can empower and enrich people, their economy, and the surrounding environment. So often, the international community has portrayed Bangladesh as a source of (illegal) migrants to other countries. McAdam (2013) rightly suggested that Bangladesh's climatic displacement was largely attributable to internal factors [4]. Although Bangladesh has dramatically reduced the number of cyclone victims and improved disaster responses in the last 50 years, if these actions were not enough to entice many to stay and contribute to their own country, what else Bangladesh can do? Although this question is beyond the scope of this paper, we would still argue that more comprehensive rural development actions are needed to empower and enrich rural people. For example, cluster villages we examined in this paper can go beyond lifesaving and livelihood-maintenance places. Disaster responses may create more opportunities for good education and job opportunities.

Author Contributions: Conceptualization, C.K. and K.M.; methodology, C.K. and K.M.; analysis, C.K. and K.M.; investigation, C.K.; data curation, C.K. and K.M.; writing-original draft preparation, C.K.; writing-review and editing, K.M.; supervision, K.M. All authors have read and agreed to the published version of the manuscript.

Funding: This study was supported by a fellowship from the Project for Human Resource Development Scholarship (JDS) by Japanese Grant Aid, Japan International Cooperation Center (JICE), Nishi-Shinjuku, Tokyo, Japan.

Institutional Review Board Statement: Not applicable.

Informed Consent Statement: We explained the purpose of the study to the officials mentioned in the study and interviewed them after they agreed.

Data Availability Statement: Not applicable.

Conflicts of Interest: The authors declare no conflict of interest.

\section{References}

1. Intergovernmental Panel on Climate Change (IPCC). Climate Change 2014: Impacts, Adaptation, and Vulnerability. Part A: Global and Sectoral Aspects. Contribution of Working Group II to the Fifth Assessment Report of the Intergovernmental Panel on Climate Change; Field, C.B., Barros, V.R., Dokken, D.J., Mach, K.J., Mastrandrea, M.D., Bilir, T.E., Chatterjee, M., Ebi, K.L., Estrada, Y.O., Genova, R.C., et al., Eds.; Cambridge University Press: Cambridge, UK, 2014.

2. Heslin, A.; Deckard, N.D.; Oakes, R.; Montero-Colbert, A. Displacement and Resettlement: Understanding the Role of Climate Change in Contemporary Migration. In Loss and Damage from Climate Change; Climate Risk Management, Policy and Governance; Mechler, R., Bouwer, L., Schinko, T., Surminski, S., Linnerooth-Bayer, J., Eds.; Springer: Cham, Switzerland, 2018 ; pp. 237-258. [CrossRef] 
3. Alston, M. Women and Climate Change in Bangladesh; Routledge: New York, NY, USA, 2015.

4. McAdam, J. Climate Change, Forced Migration, and International Law; Oxford University Press: Oxford, UK, 2013.

5. Benzie, M.; Persson, Å. Governing Borderless Climate Risks: Moving Beyond the Territorial Framing of Adaptation. Int. Environ. Agreem. Polit. Law Econ. 2019, 19, 369-393. [CrossRef]

6. McLeman, R. Climate Change and Adaptive Human Migration: Lessons from Rural North America. In Adapting to Climate Change: Thresholds, Values, Governance; Adger, W.N., Lorenzoni, I., O’Brien, K., Eds.; Cambridge University Press: Cambridge, UK, 2009; pp. 296-310.

7. de Sherbinin, A.; Castro, M.; Gemenne, F.; Cernea, M.M.; Adamo, S.; Fearnside, P.M.; Krieger, G.; Lahmani, S.; Oliver-Smith, A.; Pankhurst, A.; et al. Climate Change. Preparing for Resettlement Associated with Climate Change. Science 2011, 334, 456-457. [CrossRef] [PubMed]

8. Thomas, A.; Benjamin, L. Policies and mechanisms to address climate-induced migration and displacement in Pacific and Caribbean small island developing states. Int. J. Clim. Chang. Strateg. Manag. 2018, 10, 86-104. [CrossRef]

9. General Economic Division (GED). Accelerating Growth, Empowering Citizens; The 7th Five Year Plan 2016-2020; Government of Bangladesh: Dhaka, Bangladesh, 2015. Available online: https://policy.asiapacificenergy.org/node/2443 (accessed on 2 May 2020).

10. Nishat, A.; Mukherjee, N. Climate Change Impacts, Scenario, and Vulnerability of Bangladesh. In Climate Change Adaptation Actions in Bangladesh; Shaw, R., Mallick, F., Islam, I., Eds.; Springer: Tokyo, Japan, 2013; pp. 15-41. [CrossRef]

11. Ministry of Environmental, Forest, and Climate Change (MOEFC). Bangladesh Climate Change Strategy and Action Plan (BCCSAP) 2009; Ministry of Environment, Forest and Climate Change; Bangladesh Secretariate: Dhaka, Bangladesh, 2009. Available online: https:/ / moef.gov.bd/ (accessed on 2 May 2020).

12. The World Bank. Bangladesh: Building Resilience to Climate Change. 9 October 2016. Available online: https://www.worldbank org/en/results / 2016/10/07/bangladesh-building-resilience-to-climate-change (accessed on 7 February 2021).

13. Kazi, S. Bangladesh's 50 Years Journey to Climate Resilience. World Bank Blogs. 12 November 2020. Available online: https: //blogs.worldbank.org/endpovertyinsouthasia/bangladeshs-50-years-journey-climate-resilience (accessed on 7 February 2021).

14. Haque, U.; Hashizume, M.; Kolivras, K.N.; Overgaard, H.J. Reduced death rates from cyclones in Bangladesh: What more needs to be done? Bull. World Health Organ. 2012, 90, 150-156. [CrossRef] [PubMed]

15. Walsham, M. Assessing the Evidence: Environment, Climate Change, and Migration in Bangladesh; International Organization for Migration, Regional Office for South Asia: Dhaka, Bangladesh, 2010. Available online: https://publications.iom.int/books/ assessing-evidence-environment-climate-change-and-migration-bangladesh (accessed on 2 April 2020).

16. Ahmad, M. Fighting Hazards and Saving People: Disaster Management in Bangladesh. In Asian Experiences in Disaster Management: Challenges and Prospects for the Future; Asian Resource Foundation: Bangkok, Thailand, 2013; pp. 63-76.

17. Patwary, O.H. Climatic Change and Displacement: The Case of Bangladesh. Int. J. Arts Sci. 2016, 9, 565-580. Available online: https:/ / www.researchgate.net/publication/319939100 (accessed on 2 April 2020).

18. Haque, M.; Pervin, M.; Sultana, S.; Huq, S. Towards Establishing a National Mechanism to Address Losses and Damages: A Case Study from Bangladesh. In Loss and Damage from Climate Change Concepts, Methods and Policy Options; Mechler, R., Bouwer, L., Schinko, T., Surminski, S., Linnerooth-Bayer, J., Eds.; Springer: Cham, Switzerland, 2018; pp. 451-473. [CrossRef]

19. Rahman, M.S.; Gain, A. Adaptation to riverbank erosion-induced displacement in Koyra Upazila of Bangladesh. Prog. Disaster Sci. 2020, 5, 1-8. [CrossRef]

20. Mallick, B.; Ahmed, B.; Vogt, J. Living with the Risks of Cyclone Disasters in the South-Western Coastal Region of Bangladesh. Environments 2017, 4, 13. [CrossRef]

21. Mallick, B.; Sultana, Z. Livelihood after Relocation-Evidences of Guchchagram Project in Bangladesh. Soc. Sci. 2017, 6, 76. [CrossRef]

22. Barua, P.; Rahman, S.H. Integration of Community-Based Rehabilitation Program for Defensible Solution of Climate Displacement Problem in the Coastal Area of Bangladesh. Aust. J. Sci. Technol. 2018, 2, 169-176.

23. Arnall, A. Resettlement as Climate Change Adaptation: What Can Be Learned from State-led Relocation in Rural Africa and Asia? Clim. Dev. 2018, 11, 253-263. [CrossRef]

24. Kaluarachchi, Y. Building community resilience in the re-settlement of displaced communities. Procedia Eng. 2018, 212, 443-450. [CrossRef]

25. Ministry of Land (MOL). The Climate Victims Rehabilitation Project (CVRP) Guchhogram-2 (the Cluster Village Project-2); Government of Bangladesh: Dhaka, Bangladesh, 2017. Available online: https://www.guchhogram.gov.bd/about-guchcchogram/ (accessed on 30 June 2020). (In Bengali)

26. Saito, N. Mainstreaming Climate Change Adaptation in Least Developed Countries in South and Southeast Asia. Mitig. Adapt. Strateg. Glob. Chang. 2013, 18, 825-849. [CrossRef]

27. Ministry of Law. The Land Reform Ordinance, 1984 (Ordinance No. X of 1984); Legislative and Parliamentary Affairs Division, Ministry of Law, Government of Bangladesh: Dhaka, Bangladesh, 2019. Available online: http://bdlaws.minlaw.gov.bd/act-665. html (accessed on 15 May 2020).

28. Char Development and Settlement Project (CDSP). Brochures: Char Development and Settlement Project Phase IV at a Glance; Ministry of Land, Government of Bangladesh: Dhaka, Bangladesh, 2017. Available online: https://cdsp.org.bd/ (accessed on 1 January 2021). 
29. Ministry of Land (MOL). The Agricultural Khasland Settlement and Management Policy of 1997; Land Administration Manual, Part 3; Ministry of Land, Government of Bangladesh: Dhaka, Bangladesh, 1997; pp. 179-194. Available online: https://minland.gov.bd/ (accessed on 15 May 2020). (In Bengali)

30. Prime Minister Office. The Ashrayan-2 Project Implementation Guideline. In The Ashrayan (Housing)-2 Project, 2nd ed.; Government of Bangladesh: Dhaka, Bangladesh, 2019. Available online: http:/ / ashrayanpmo.gov.bd/ (accessed on 15 May 2020). (In Bengali)

31. Vij, S.; Biesbroek, R.; Groot, A.; Termeer, K. Changing climate policy paradigms in Bangladesh and Nepal. Environ. Sci. Policy 2018, 81, 77-85. [CrossRef]

32. General Economic Division (GED). Steps towards Change. National Strategy for Accelerated Poverty Reduction (NSAPR) II (Revised) FY2009-11; General Economics Division, Planning Commission, Government of Bangladesh: Dhaka, Bangladesh, 2009. Available online: https:/ / planipolis.iiep.unesco.org/sites/default/files/ressources/bangladesh_nsapr_ii.pdf (accessed on 2 May 2020).

33. General Economic Division (GED). The Perspective Plan of Bangladesh 2010-2021: Making Vision 2021 a Reality; General Economics Division, Government of Bangladesh: Dhaka, Bangladesh, 2012. Available online: https://unctad.org/system/files/non-officialdocument/dtl_eWeek2018c03-bangladesh_en.pdf (accessed on 2 May 2020).

34. Bangladesh Climate Change Trust (BCCT). The Climate Change Trust Act, 2010, Act No. LVII of 2010; Ministry of Environment and Forest, Government of Bangladesh: Dhaka, Bangladesh, 2016. Available online: http://www.bcct.gov.bd/site/view/ commondoc/Project\%20Guideline/- (accessed on 31 March 2021).

35. National Disaster Management Policy (NDMP). National Disaster Management Policy 2015; Ministry of Disaster Management and Relief, Government of Bangladesh: Dhaka, Bangladesh, 2015; pp. 7243-7290. Available online: http://www.ddm.gov.bd/ (accessed on 2 May 2020).

36. Standing Orders on Disaster (SOD). Standing Orders on Disaster 2019; Ministry of Disaster Management and Relief, Government of Bangladesh: Dhaka, Bangladesh, 2019; pp. 59-86. Available online: http://www.ddm.gov.bd/site/view/policies/ (accessed on 27 August 2020). (In Bengali)

37. National Plan for Disaster Management (NPDM). National Plan for Disaster Management 2010-2015; Disaster Management Bureau, Ministry of Disaster Management and Relief, Government of Bangladesh: Dhaka, Bangladesh, 2010. Available online: http:/ / extwprlegs1.fao.org/docs/pdf/bgd146945.pdf (accessed on 2 May 2020).

38. Chowdhury, S. Climate Change Adaptation Policy Actions in the Coastal Areas of Bangladesh. Master's Thesis, Graduate School of Life and Environmental Sciences, University of Tsukuba, Tsukuba, Japan, July 2018.

39. Tanjim, M. A Study on the Mainstreaming of Bangladesh Climate Change Strategy and Action Plan in the Health and Gender Sectors of Bangladesh. Master's Thesis, Graduate School of Life and Environmental Sciences, University of Tsukuba, Tsukuba, Japan, July 2020.

40. Sharif, I.; Nasir, N.; Khanum, R.; Khan, A.S. Climate Change Adaptation Policies in Bangladesh: Gap Analysis through a Gender Lens. BRAC Univ. J. 2016, 11, 11-15.

41. Finance Division (FD). Climate financing for sustainable development. In Budget Report 2018-2019; Government of Bangladesh: Dhaka, Bangladesh, 2020. Available online: https:/ / mof.gov.bd (accessed on 27 August 2020).

42. Ministry of Law. The Local Government (Union Parishad) Act, 2009. In Laws of Bangladesh; Government of Bangladesh: Dhaka, Bangladesh, 2009. Available online: http:/ /bdlaws.minlaw.gov.bd/ (accessed on 20 April 2020). (In Bengali)

43. Local Government Division (LGD). The Upazila Parishad (Amendment) Act 2011; Local Government Division; Ministry of Local Government and Engineering, Government of Bangladesh: Dhaka, Bangladesh, 2011; pp. 15085-15099. Available online: https:/ /lgd.portal.gov.bd (accessed on 2 February 2021). (In Bengali)

44. Prime Minister Office. Annual Report 2019-2020; The Ashrayan 2 Project; Government of Bangladesh: Dhaka, Bangladesh, 2020. Available online: http:/ / www.ashrayanpmo.gov.bd/ (accessed on 22 March 2021). (In Bengali)

45. Ministry of Land (MOL). The Bangladesh Land Holding (Limitation) Order, 1972 (President's Order No. 98 of 1972); Land Administration Manual, 4th Chapter: Land Reform; Ministry of Land, Government of Bangladesh: Dhaka, Bangladesh, 1972; pp. $217-223$.

46. Alom, M. Flood: Relief Disbursement, Distribution, Live Saving and Nutrition. The Daily Prothom Alo 22 August 2017. Available online: https: / www.prothomalo.com/ (accessed on 25 March 2021).

47. Zetter, R. Protecting Environmentally Displaced People: Developing the Capacity of Legal and Normative Frameworks; Research Report; Refugee Studies Centre; Oxford Department of International Development, University of Oxford: Oxford, UK, 2011. 